vertised as being able to ascend a 50 percent grade, and this fact was undeniably demonstrated one day when the car was driven all the way up the west steps of the Capitol.

According to an article which appeared in the November 11, 1951 issue of the Cedar Rapids Gazette, "Since the inception of the industry (automobile) in 1890, eight of the 1775 cars produced in the United States were made in Iowa." Although this estimate may be inaccurate, it is interesting to note the eight cars named in the article: the Adams Farwell, made at Keokuk in the year 1904; the Colby, made in Mason City from 1911-13 by the Colby Manufacturing Co.; the L.C.E., produced by L. C. Erbes during the years 1915-16 at Waterloo and Jackson, Michigan; the Mason Motor Car Company, produced two cars at Waterloo; the Spaulding, produced in Grinnell from 1913-17 (it also was listed twice); and the "Iowa" (no other information given).

The Department of History and Archives is truly grateful to the Maytag Company for donating to the State of Iowa this magnificent product of early car manufacturing in Iowa.

\title{
A Short History of The Mental Health Institute at Mount Pleasant 1855-1899
}

\section{By Gregory Calvert}

Mr. Calvert, a native of Muscatine, Iowa, studied History at Iowa Wesleyan College in Mount Pleasant. While a student there he worked as an aide at the Mental Health Institute and became interested in the history of the hospital. In hearing numerous stories of the Hospital's early days, $\mathrm{Mr}$. Calvert felt there was a need to sort fact from fiction, and when the opportunity arose in the form of a research course, he set about to research and write the following article.

Before a meeting of the Fifth General Assembly of the Iowa State Legislature in 1855, Governor George Grimes proposed that a state institution for the insane be established in southeast Iowa. On January 24, 1855, the General Assembly appropriated $\$ 4,425$ for purchase of an acreage. The law 
specified that an additional sum of $\$ 50,000$ could be spent to house the State of Iowa's first mental hospital. A two-man committee consisting of General Edward Johnson of Lee County and Dr. Charles Clark of. Henry County located the institution and procured supervision for its construction. On March 17, 1855 , in the Henry County recorder's office, the first transfer of land for the new institution was made. The west one half of the Northeast quarter of Section 15 and the east one half of the Northwest quarter of Section 15 sold for $\$ 25$ per acre. The plot, totaling 173 acres, was sold to the State of Jowa by the party of Huldah-Evans, a local farmer and his wife. ${ }^{1}$

Dr. Luther Bell of Boston was the architect and Mr. Henry Winslow was the construction Superintendent when construction began in October, 1855. The plan prescribed a structure of Elizabethan style built of solid cut stone. The building had a central structure of four stories and three wings extending to each side. Each wing was three stories tall and each side was topped by a cupola rising 90 feet from the ground. The central structure measured 90 feet long by 60 feet wide. A splendid double stairway wound up through the several floors to a rotunda 49 feet by 57 feet. A tower surmounted the structure and peaked 137 feet from the ground. The central struature extended to the rear 115 feet housing a kitchen, bakery, dining room and storehouse. On the second story was a 38-foot by 50-foot chapel with a twenty-foot ceiling.

The lateral wings contained: 220 single rooms, each 12 feet by 8 feet, 18 dormitories each 18 feet by 20 feet, 18 parlors each 18 feet by 24 feet, 18 dining rooms 16 feet by 24 feet, 18 corridors 12 feet by 112 feet each, 24 bathing rooms, 25 water closets, and 78 clothes closets. ${ }^{2}$ The completed building contained 425 rooms, 1100 windows, 900 doors and over one mile of hallways. The heating system, the forced ventilation system, and even the laundering facilities were all powered by a steam system. Over twelve miles of iron pipe was needed to carry the steam throughout the hosiptal. ${ }^{3}$

The institution was completely piped for gas lights. It wasn't until 1868, however, that the lights were finally installed. During the interim, kerosene was used. While the 
hospital was being built, the Board of Trustees was busy writing the by-laws of the institution prescribing the conditions for admission to the hospital. They sent a copy to each county judge in the state. Besides the task of writing the by-laws, the Board was shackled with the responsibility of picking a suitable Superintendent. They chose Dr. R. J. Patterson as the hospital's first Superintendent at a salary of $\$ 1200$ per year.

On February 27, 1861, the doors officially opened and the hospital began to fill rapidly. The jails, almhouses, county homes, and poorhouses of Iowa sent dozens of people to Mount Pleasant. The three hundred beds were quickly filled. In the first three months over 100 were admitted. ${ }^{4}$ By 1862 , there were already 216 patients in the hospital at a per capita cost of three dollars per week. ${ }^{5}$ By 1864 overcrowding was becoming a problem; the official census showed 284 patients and in early 1865, the hospital was filled. ${ }^{6}$ The 1866 Superintendent's report to the State General Assembly contained a plea for allocation of $\$ 75,000$ for construction of additional facilities for 75 patients. It wasn't until 1884 that any money was appropriated for extending the facilities. The hospital opened with a very inadequate water supply available. In 1866 , a reservoir was constructed together with a pump house, to supply the hospital with an adequate amount of fresh water. The completed reservoir was 200 feet in diameter and $12{ }^{1 / 2}$ feet deep. ${ }^{7}$ Water was supplied to the wards by pumping from the reservoir, through the pumphouse to the attics of several of the buildings where it drained to the floors below. This gravity flow system supplied the hospital until the early 1890's when an artisian well was dug.

By 1868 , overcrowding was a serious problem in the hospital. The 300 beds were all filled, forcing more than 100 additional patients to sleep on mattresses and cushions in hallways and dormitories. Also in 1868, 120 additional acres were purchased; 40 acres on the west and 80 acres on the south. The total acreage in 1870 was 293 acres, most of which was cultivated for supplying the hospital with meat and vegetables, fruit and milk. The 1868 farm report listed the following as part of its exhibit of supplies on hand and their value: ${ }^{8}$ 


$\begin{array}{lr}32 \text { Milch Cows } & \$ 1440.00 \\ 1 \text { Calf } & 40.00 \\ 16 \text { Old Sows } & 288.00 \\ 6 \text { fat hogs } & 180.00 \\ \text { Corn, oats and prairie hay } 1138.55 \\ 1 \text { boar } & 40.00 \\ 9 \text { horses, } 6 \text { mules } & 2320.00\end{array}$

The cooling of dairy products, vegetables, and meats was constantly a problem. In 1868, the General Assembly approved an appropriation for an ice house 24 feet by 24 feet with a depth of 16 feet. The building had a six-inch space between the inner and outer walls which was filled with sawdust to insure insulation. However, the hospital would soon outgrow the space available in that building and in 1890 , another was built.

In muddy weather, travel from the front gate of the hospital to the main entrance of the building, a distance of nearly one-half mile, was quite difficult. No good roads existed on the ground and freight wagons and fancy carriages were often mired to the hubs. In 1870 , the problem was alleviated somewhat with the construction of a stone and cinder road 250 rods long and 18 feet wide. A graded bed, 18 inches deep, formed the foundation which was filled with rubble rock 18 inches deep. Several inches of coal cinders on top made a quite passable surface. ${ }^{\circ}$ The road ran straight to the front of the building, then circled to the rear to a barn which was also constructed in 1870. The barn provided ten stalls for farm teams, a threshing floor and a large bay for storing hay. The structure measured 110 feet by 40 feet with a basement nine feet deep under the entire structure. ${ }^{10}$ In 1871, a chimney was constructed onto the rear of the central portion of the building. Made of stone and iron, it towered 134 feet above the ground.

In 1873, the mental hospital at Independence opened and 89 patients from Mount Pleasant were sent there thus relieving the overcrowded situation.

An administrative change in 1873 put Dr. H. M. Bassett in the Superintendent's position, replacing Dr. Mark Ranney. Dr. Bassett had been an assistant physician for nine years. 
Also in 1873, the well-known woman's cause advocate, Dorthea Dix, presented the hospital with a gift-a kaleidoscope that provided entertainment for both patients and staft.

In 1876, much of the substructure of the hospital was found to be of an inferior quality of stone and required replacing at a cost of $\$ 16,237.50 .{ }^{11}$ The big news that year, however, was a fire that gutted a rear engine building. On April 18, a patient observed sparks jumping from the roof of the two-story building and sounded the alarm. The Niagara and Worthington pumps were quickly attached and the fire was brought under control within half an hour. The cost of rebuilding was $\$ 32,046.43 .{ }^{12}$ Besides rebuilding the engine house in 1878 , a bakery and a clock tower were constructed to the rear of the central building.

A report to the General Assembly in 1878, by the Superintendent of the hospital, listed the leading causes of insanity. Persons were admitted to the mental hospital for: business anxiety, disappointments, over-exertion, excessive study, epilepsy, masturbation, intemperance, and religious excitement. ${ }^{13}$

Besides the problem of overcrowding, the early days of the hospital were filled with dread of fire and several requisitions were made to the State Legislature to supply adequate fire preventing and extinguishing equipment. Finally, in 1880, the Legislature requisitioned funds to install a fire prevention system.

Problems of heating and ventilation constantly plagued the institution. The hard water supplied to the institution corroded the pipes, and they constantly burst, thereby making less efficient the already poor heating system. Ventilation consisted of several shafts through which air was pushed by large rotors. These shafts, however, often filled with backed up sewage and little fresh air passed through them. Also, the vents to the ventilation shafts were in the floor and often accommodated nearby patients for spitoons, thereby making even more rancid the odor circulated throughout the hospital.

Through the 1880 's, the attendants in the hospital received a salary of $\$ 25$ per month for men and $\$ 15$ per month for women, both did identical work, Their duties included serving meals, cleaning the ward, supervising farm details, bathing the 
patients and maintaining the ward in a generally appropriate manner. ${ }^{14}$

In 1882, the Board of Trustees appointed Dr. H. A. Gilman to the position of Superintendent. Until 1882, Gilman had served as Superintendent at the Illinois Hospital for the Insane at Jacksonville, Illinois. In 1882, the population of the hospital had climbed to over 500 and the high death rate of 98 for that year resulted from the overcrowded conditions. ${ }^{15}$ That year, also, 118 men and 25 women slept on straw beds on the floors of the hospital corridors. ${ }^{16}$ Superintendent Gilman asked the Legislature to approve a requisition for $\$ 150,000$ to expand the facilities to maintain 300 more patients. The Legislature didn't approve the requisition in 1883.

Work continued on the fireproofing of the hospital. In $1882-1883, \$ 3,000$ was appropriated by the Legislature to fireproof the walls of the central building. ${ }^{17}$ The hospital asked for an additional $\$ 2,000$ to install a fre alarm system throughout the hospital, however, the money was not included in the governor's 1884 budget.

The 18th General Assembly voted $\$ 300$ for the installation of a telephone communication system for the hospital. ${ }^{18}$

A telephonic connection has been made with the city of Mount Pleasant, and much of our business is transacted by this agency; in addition to this, we have an annunciator in the medical office and the apparatus is so arranged that the same transmitter is used for the town line and the hospital system, a switch being used to accomplish the change from the town line to the hospital. We have the six extreme wards, boiler house, carpenter shop, and stable connected and use at each of these stations, the pony, crown, or hand telephone, and there is also a call bell in the rear kitchen. The entire appropriation of $\$ 300$ was expended for these appliances.

An appropriation of $\$ 100,000$ by the Nineteenth General Assembly in 1881 allowed construction of an additional wing to the east side of the hospital to house 200 male patients. The Legislature denied a similar proposal for a female wing. The new wing was made entirely of cut stone exterior with brick partitions between the rooms and corridors on the inside. The Superintendent's report gave a detailed account of the construction. ${ }^{19}$ Many patients under the supervision of the carpenters and attendants, contributed their skills and labor to the construction of the new wing, thereby saving money for the 
taxpayers while providing a therapeutic activity for themselves.

While the construction of the new men's wing went smoothly in 1885, the farm production for that year was the poorest of the decade. The Superintendent's report stated:

The year 1885 was a very trying one for us in regard to crops. Grasshoppers appeared in our midst in July and destroyed the most of our vegetables, a garden of 20 acres being despoiled by them and much other damage accomplished. Last year, 1886 we suffered a severe drought and all our crops were much below average per cent. ${ }^{20}$

Throughout the 1880's and 1890's a series of pathological studies was done by several assistant physicians in the hospital. The results of these studies were well documented in the Biennial Reports to the General Assembly. An 1884 report on insanity caused by tuberculosis cited bromide of potash as an effective tranquilizer. Cod liver oil and iron relieved the cough of a patient with tuberculosis.

The 21st General Assembly appropriated $\$ 100,000$ to construct and furnish a wing for female patients corresponding in design to the male wing just completed. The new wing adjoined the west side of the original structure. Patient labor helped build the female wing. This time a full 100 were employed from day to day. ${ }^{21}$

The combination of the two new wings increased the capacity of the hospital to 700 in 1887. By 1888, all of the beds were full and overcrowding was again a problem. In 1889, construction was completed on both the Anamosa and the Clarinda institutions. Both Mount Pleasant and the Independence hospitals sent patients to these new facilities.

The requisitions for appropriations in 1888 to the General Assembly included a request for $\$ 20,000$ to replace five old boilers and construct a new building to house them in. The Legislature voted in favor of the building; it was placed several hundred feet to the south of the central building and housed the boiler house, engine room, coal house and wash house. The front of the building measured 110 feet and was divided into three sections: the engine room on the west, with apartments for the engineers, firemen and laborers on the second story above it; a machine shop of one story in the center; and the wash room on the east. From the center of the machine shop, the plant extended 210 feet to the south. Just to the 
rear of it was the boiler house and the coal house. John Mohr and Son of Chicago supplied the new boilers which measured 15 feet in length with a diameter of 5 feet. $^{22}$

The purchase of 240 additional acres in 1889 allowed the Mount Pleasant hospital to increase its herd of cattle to over 100 and upped the total acreage to 580 . This was enough land to supply the hospitals entirely with the vegetables and crops it needed in addition to supplying a program of industrial therapy for many of the patients. Work on an industrial building for women began in May, 1889 and ended in December of the next year. The building, a 75 -foot by 50 -foot, two-story structure connected to the west wing of the hospital by a thirtyfoot corridor of brick, served with an ironing room, dress making room, sewing room, and mending room on the first floor and a matron's store room and sleeping quarters for domestic help on the second. ${ }^{23}$

Hospital life, in 1890 , began with the morning bell at six o'clock, the signal for all employees of the hospital to rise. The attendants first supervised all patients in getting up and clothing themselves, lending help wherever necessary. The attendants next served breakfast to all the patients. Food arrived on the ward through a system of dumb waiters and a small railroad track which ran throughout the basement of the central building and the adjacent wings. After the meal had been completed, the attendant did the daily ward work such as dusting, sweeping and mopping the floors and halls. All was made ready for the doctor's morning visit.

\section{As Superintendent Gilman described it;}

The physicians make their morning visits at nine o'clock through the wards, noting carefully the condition of each patient and attending to their physical, moral, and dietetic treatment, allaying their fears and delusions and by their influence, soothing the disturbed and irritable. ${ }^{24}$

After the morning visit by the doctors, as many patients as could go, worked on work details to the garden, farm, stable; boiler house, kitchen, bakery, or as laborers whenever any building operations were going on. The women patients went to the ironing room, dress-making, sewing, and mending rooms to assist.

At twelve o'clock, the attendants dished up dinner, a 
hearty meal of meat, bread, vegetables, fruit and milk, made to restore the physical health of the patients in hopes of thereby bolstering their mental conditions. By one o'clock the attendants had cleaned the dining rooms and the afternoon's activities were ready to begin. In addition to work details, as in the morning, in the afternoon, a carriage ran about the grounds giving rides to those who were unable to exercise on their own.

The Superintendent spent his afternoons receiving and conversing with the friends of the patients. There were no social workers at that time. In addition to his role as a social worker, the Superintendent might have been seen visiting the wards, supervising building activities, conferring with the steward or assisting one of the physicians. The State required a deal of service for $\$ 1,500$ per year.

The attendants prepared a daily report and entered it in the permanent files at the end of the day. The physician often visited the ward late in the afternoon. At six o'clock p.m. supper was served. Then patients were free to stroll about the grounds or to attend scheduled activities for an hour. Many retired shortly after supper and the lights went out at ten for both patients and employees living on the grounds.

Today's mental hospitals have established recreation departments whose only activity is to plan amusements for the patients. In 1890 however, there was no established recreation department. Nevertheless, a fairly constant program of entertainment and amusement occupied long winter evenings and holidays. On Monday evening, the literary society met with a varied program of music, literary exercises and discussions. On Tuesday, an orchestra composed of staff members provided music for the weekly dance, and on Wednesday and Friday evenings, drama filled the evening; both staff and patients participated. Thursday evening highlighted the week with exhibitions of pictures of cities, landscapes, and public buildings in the U.S.A. and foreign countries, accompanied by a lecture by one of the physicians. On all holidays, special programs entertained the staff and patients. The Holiday Programs began on Thanksgiving, with a feast of good things during the day and entertainment in the evening. Christmas, New Years, 
Washington's Birthday, May Day, Decoration Day and July Fourth, both staff and patients held celebrations and halted all formal business of the hospital. At Christmas time, friends of each patient sent some token of the season to be hung on the tree. If the patient had no friends, the contributions of outside parties who had become interested usually made it possible for every patient in the hospital to receive some momento of the occasion. ${ }^{25}$

The various pastors of the different churches in Mount Pleasant held religious services every Sunday at three o'clock p.m. Methodist, Baptist, Catholic, Episcopalian, Presbyterian, and Congregationalist pastors served for the good of the hospital's 600 patients. After 1891, services were held in the new chapel which seated the entire hospital population in finished oak pews in a main audience room and gallery. A fine new organ was purchased from Johnson and Son, Westfield, Mass. and provided music for the services. ${ }^{203}$ The same year saw the construction of an amusement hall with a spacious stage with eight complete changes of scenery for dramatic entertainments, concerts, etc. The hall contained removable seats for dances and a gallery or balcony to increase the capacity. The added attraction of frescoed walls made the hall bright and cheerful.

For the treatment of mental illness in the days before modern medicine, much emphasis was put on a healthful diet and a pleasant atmosphere. The hospital spared little expense in creating an enjoyable atmosphere. From time to time, the General Assembly appropriated funds to landscape the grounds, surface the sidewalks, and even to build small sitting houses to be placed about the grounds. The diet of the patients consisted of ample quantities of staple foods-milk, bread, vegetables, meat and fruits. The treatment plan relied heavily upon the ability of a healthy diet and a pleasant atmosphere to "restore the light of reason to those whose had flickered out." The physicians of one hundred years ago did, however, attempt some medical treatment of mental disorders. ${ }^{27}$ A report to the General Assembly in 1891 by the Superintendent of the Mount Pleasant hospital stated:

. . .for purposes of restoring general health, and toning up the nervous system, the tonics of quinine or Cinchona, Gentian, 
Nux Vomica or strychine, Columbo and syrup of hypophosphite, cod liver oil and in cases of extreme exhaustion to tide over the danger line, in moderation, the malt liquors and alcoholic stimulants may be used . . . In cases of cerebral congestion it is important to envelope the head in applications of ice, either by the use of the ice cap or bag or if a nurse can be with the patient constantly, direct applications to the head.

In addition, for melancholia, some form of opiate was recommended, more specifically, a form of opium or dried marijuana.

The problem of the training of aides and nurses to the peculiar task of aiding the mentally ill plagued the hospital even in the 1890's. In 1.891, Superintendent Gilman proposed the establishment, by the state, of training schools for aides and nurses. The proposal suggested that the University of Iowa create a department to thoroughly train and instruct young men and women. From these graduates, the hospital would pick: ${ }^{28}$

Those persons as are best adopted by nature and education for

the vocation so important and sacred as to call for the best possible efforts of those who undertake it as a profession.

The 24th General Assembly appropriated $\$ 20,500$ to the Mount Pleasant institution for special purposes to be spent during the fiscal years $1892-93{ }^{29}$ Specifically, there were appropriations for: better fire protection; general repairs of the physical plant; repainting parts of the institution; improvement of the grounds, and repairing the hospital's sewers.

The appropriation for better fire protection consisted of $\$ 10,000$ to be spent laying a six inch pipe from Washington street to the building. Hydrants were placed at convenient distances along the pipe. In addition, the hospital purchased 200 feet of fire hose and a host cart with the appropriation. The 25th Legislature voted money for fire escapes and fire pumps.

The appropriation for painting accomplished the renewing of five wards and the roofs of most of the buildings. The allocation for sewer repair revamped the hospital's sewage disposal system replacing old brick pipe with new vitrified metal pipe and created a new system of waste disposal utilizing a cesspool located several hundred yards from the hospital.

The state financed the cost for landscaping, improving walks, and purchasing additional lawn chairs and sunhouses. It was not until 1898 that the first cement sidewalks from Washington Street to the central buildings were completed. 
By 1894, the hospital was again overcrowded. The Superintendent and the Board of Trustees appealed to the legislature to appropriate funds to complete other State institutions and also requested funds for the construction of infirmary buildings for both men and women. The Superintendent also beseeched the Legislature to adopt means of educating the general population to the causes of mental illness in hopes of preventing future overcrowding and to stop the alarming rise of mental illness in the state. ${ }^{30}$

The 1896 Governor's budget granted $\$ 20,000$ to the Mount Pleasant institution for construction of an infirmary for aged men. Built of brick with a stone foundation, the infirmary contained dormitories, halls, dayrooms, dining rooms, kitchens and skullery for 50 men. Within three years, the State allocated funds for a similar women's infirmary thereby relieving the overcrowding to some degree.

By the late 1890's, the hospital owned 580 acres of land and produced most of the meat and vegetables required to feed its 800 patients. The per capita cost was $\$ 14$ per month, roughly $46 \phi$ per day for food, clothing, shelter, and treatment.

In 1898 the Mental Health Institute came under the control of the State Board of Control. Chapter 118 of the Acts of the 27th General Assembly, passed on March 26, 1898, provided for a Board of Control of State Institutions to be established. The law vested that Board with full power to manage, control and maintain the Soldier's Home, the State Hospitals for the Insane, the college for the Blind, the school for the Deaf, the Institution for the Feebleminded, the Soldier's Orphan's Home, the Industrial Home for the Blind, the two Industrial Schools, and the State penitentiaries. The Board consisted of three men appointed by the Governor and approved by the State Senate to serve for salaries of $\$ 3,000$ per year. Duties of the Board included the publication of biennial reports to the Legislature and the yearly publication of expenditures of the institutions.

The aim of the Iowa Legislators in creating a State Board of Control must surely have been the standardization of the State Institutions and the inherent economic advantage of the unity provided by single control over the allocation and expenditure of State funds. This writer feels, however, that 
there were definite disadvantages in the removal of the autonomy of the State Institutions. The unique personality of each institution succumbed to the standardization of the State's bureaucratic machinery. The hospital in Mount Pleasant must certainly have sacrificed much of the healthful, homelike atmosphere, thought so important in the treatment of the mentally disturbed, when it came under the direction of the State Board of Control.

\section{Duties of the Attendants: 1860. (from the By-Laws of the Institution.)}

Sec. 56. The attendants shall have the immediate and constant care and supervision of the patients.

A few general facts and principles should be kept in mind by all persons connected with the management of the insane, but more especially, by their attendants, into whose never ceasing care and keeping they are entrusted.

1. Insanity is always connected, in some manner, with bodily infirmaty. 2. There is usually a loss of all sense of moral obligation or ability to distinguish between right and wrong, and, therefore irresponsibility for words and actions.

3 . There is a full appreciation of all acts of kindness and cruelty and in general, a perfect recollection of them after restoration and in after life. 4. There is usually a morbid or exalted sensitiveness in relation to what is due them in attention and deportment and consequently, irritation, excitement or anger at real or imagined neglect or impropriety of treatment.

5 . The frequent recurrence of excitements aggravates and perpetuates the disease.

6. The more the mind dwells upon, or is reminded of hallucinations or delusions, the more permanently are they fixed: so is the reverse true, that the more they are driven from the mind, by occupation with other thoughts and ideas, the sooner do they disappear altogether.

Those few principles are the basis of the following rules and regulations for attendants:

Sec. 57. DEPORTMENT OF PATIENTS: In all their intercourse with the patients, they must treat them with respect and civility-Address them in a mild and gentle tone of voice avoiding all violence and rudeness or undue familiarity, nicknames, or disrespectful terms. All civil questions are to be properly answered; All reasonable requests promptly attended to. They must never speak to them of their delusions, nor to others in their hearing; Never allow them to be laughed at or ridiculed, or harshly spoken to on account of their delusions or peculiarities. Deception is never to be used, nor promises made without expecting their fulfillment.

They should never manifest fear of a patient, should keep calm under every provocation, never scold, threaten, or dictate authoritatively. When firmness and decision are required, it should be with mildness and kindness. When force is required, if it be with tact and kindness, a pleasant smile, cheerful and explanatory words, and sympathizing man- 
ner, but little will be needed. Under no circumstances will a kick, a blow, or similar violence be excused, except in the dearest case of self defense. Sec. 58. DEPORTMENT GENERALLY

Attendants are required to be neat and cleanly in their dress, courteous and respectful to the officers, to one another and to all others; never wearing their hats indoors; or going in their shirtsleeves; never to use profane or vulgar language; never to lounge upon the tables or other furniture, or upon the floor; never to be noisy or boisterous, to be always cheerful, but without unbecoming levity, and to be respectfully gentlemanly or ladylike in all things.

When abroad they are never to report the conduct, conversation, peculiarities or even the names of patients; and never to speak disrespetfully of the Institution or its officers.

Sec. 59. OF RISING, AND ETC.

They must rise punctually at the sound of the morning bell and take charge of the hall, open the bedroom doors of the patients, give them a cheerful greeting, see that they are properly washed and dressed, clothing and shoes, all brushed, hair combed, and in good order. Immediately upon rising, all beds are to be opened for airing, foul ones to be removed, and when sufficiently aired, they are to be made up, the bedrooms and halls swept, and everything put in the best of order and thus maintained throughout the day.

Sec. 60. OF MEALS.

They are to see that all patients are up, and prepared for breakfast at the prescribed hour, and duly ready for all other meals-all patients to partake at the table, except when sick, when confined to their rooms, or when otherwise directed. The food is to be promptly served by the Attendants whilst warm and in good order, not only to those at the table but to those in their rooms or lodges. Those confined are to be served first. At table the preferences of patients their likes and dislikes and peculiarities as to taste and desire, are, as far as possible to be attended to. Knifes and forks, or other dangerous weapons, are never to be left in the possession. After each meal they are to be counted. And if any are missed, prompt measures must be taken for their recovery. Immediately after each meal, the dining room must be put in complete order for the next. Attendants must not linger at their own meals nor in going to them or from them.

Sec. 61. OF CLEANLINESS.

Every part of the halls, rooms and verandahs must be kept scrupulously neat and clean. Nothing is clean enough that can be made cleaner. All the floors must be scrubbed weekly, and oftener when necessary, and must be swept each day as often as required to keep them clean. Water closets and urinals are to be frequently inspected and kept clean. When unpleasant odors are observed the cause must be removed instantly. Clean sheets and pillow cases are to be put on each bed at least once a week and oftener if required by being soiled.

Sec. 62. OF MEDICINE.

The attendants must give all medicine as instructed by the physicians. Patients are never to be forced to take medicine, food or baths. Any striking or unexpected effect of medicine must be promptly reported. New cases of sickness must be reported immediately. Medicine cases must be kept locked. 
Sec. 63. OF BATHING.

All patients must be bathed once a week in tepid water.

Sec. 64. OF SHAVING.

This to be done by the attendants at stated intervals, twice weekly, or as directed by the superintendent. Patients must never shave themselves or handle razors. The shaving must be done in the hall spaces, or attendants parlors, or some other separate room with no patients present but those being shaved.

Sec. 66. OF WALKING.

All patients not too feeble or violent should be got out into the ground and open air daily, in suitable weather. Attention must be given to prevent elopements, delivery or reception of articles or letters, buying or soliciting tobacco, or anything else prohibited.

Sec. 67. OUT-OF-DOOR WORK.

For the benefit of patients they will be permitted and encouraged to engage in outdoor work under the care of attendants. The attendants must work with the patients, and be careful not to appear to be ordering or superintending but to direct by example and etc.

Sec. 72 .

GENERAL RULES

The whole time the attendants should be devoting themselves to the Institution, and any other application of their time can only be made by permission. They are to perform cheerfully all duties assigned to them. They must never retire to their rooms for reading, writing, sewing, or napping during duty hours. They must not lend or lose their keys.

Sec. 75 .

All persons employed, must expect an unceasing observation of the manner of performing their duties and must receive suggestions and corrections kindly and without offense.

Sec. 78.

No conversation shall be held with patients through the windows by any person whatever.

Sec. 81 .

No officer, attendant, or other person employed in or about the institution, shall at any time use intoxicating liquors of any kind at home or abroad. They shall not use tobacco, by chewing or smoking, on or about the premises; nor will the practice of profane swearing, or other immoral conducts be tolerated under any circumstances. As the use of tobacco, from its universally injurious effects upon the physical and mental faculties its strictly prohibited by patients, it is inconsistent and unjust that the officers or attendants should use it; and if any person in this important charge is unwilling to make this effort of self denial, it is better for himself and others that his labors should be in some other sphere where the practice can be admitted with less impropriaty.

\section{NOTES}

${ }^{1}$ Henry County Transfer of Lands Record 1836-1866, p. 176.

${ }^{2}$ Board of Trustees, Superintendent, and Treasurer of the Iowa Hospital for the Insane at Mount Pleasant, First Biennial Report to the General Assembly, p. 17.

IIbid., p. 17.

${ }^{4}$ Ibid., p. 7.

${ }^{5}$ Board of Trustees, Superintendent, and Treasurer of the Iowa Hos- 
pital for the Insane at Mount Pleasant, Second Biennial Report to the General Assembly, p. 1.

${ }^{6}$ Board of Trustees, Superintendent, and Treasurer of the Iowa Hospital for the Insane at Mount Pleasant, Third Biennial Report to the General Assembly, p. 47.

${ }^{7}$ Board of Trustees, Superintendent, and Treasurer of the Iowa Hospital for the Insane at Mount Pleasant, Fourth Biennial Report to the General Assembly, p. 45.

${ }^{8}$ Board of Trustees, Superintendent, and Treasurer of the Iowa Hospital for the Insane at Mount Pleasant, Fifth Biennial Report to the General Assembly, p. 44.

${ }^{\circ}$ Board of Trustees, Superintendent and Treasurer of the Iowa Hospital for the Insane at Mount Pleasant, Sixth Biennial Report to the General Assembly, p. 26.

${ }^{10}$ Ibid., p. 32.

${ }^{1}$ Board of Trustees, Superintendent, and Treasurer of the Iowa Hospital for the Insane at Mount Pleasant, Ninth Biennial Report to the General Assembly, p. 1.

${ }^{12}$ History of Henry County, (Iowa), 1879, p. 432.

${ }^{13}$ Board of Trustees, Superintendent, and Treasurer of the Iowa Hospital for the Insane at Mount Pleasant, Tenth Biennial Report to the General Assembly, 1879, State Printer, p. 42.

${ }^{14}$ Board of Trustees of the Iowa Hospital for the Insane at Mount Pleasant, By-Laws of the Institution, p. 432-438. (A more detailed acaccount of the attendants' duties can be found in appendix.)

${ }^{15}$ Board of Trustees, Superintendent, and Treasurer of the Iowa Hospital for the Insane at Mount Pleasant, Twelfth Biennial Report to the General Assembly, (Des Moines: State Printer, 1883.), p. 7.

${ }^{16}$ Ibid., p. 17.

${ }^{17}$ Ibid., p. 15.

${ }^{18}$ Ibid., p. 15.

${ }^{19}$ Board of Trustees, Superintendent, and Treasurer of the Iowa Hospital for the Insane at Mount Pleasant, Thirteenth Biennial Report to the General Assembly, (Des Moines, State Printer, 1885.), p. 16-18.

${ }^{20}$ Board of Trustees, Superintendent and Treasurer of the Iowa Hospital for the Insane at Mount Pleasant, Fourteenth Biennial Report to the General Assembly. (Des Moines, State Printer, 1887.), p. 26.

${ }^{21}$ Ibid., p. 16.

${ }^{22}$ Board of Trustees, Superintendent and Treasurer of the Iowa Hospital for the Insane at Mount Pleasant, Fifteenth Biennial Report to the General Assembly, (Des Moines, State Printer. 1887), p. 13.

${ }^{23}$ lbid., p. 15.

${ }^{24}$ Ibid., p. 21.

${ }^{25}$ Ibid., p. 24.

${ }^{26}$ lbid., p. 21-22.

${ }^{27}$ Ibid., p. 23.

${ }^{28}$ Board of Trustees, Superintendent and Treasurer of the Iowa Hospital for the Insane at Mount Pleasant Seventeenth Biennial Report to the General Assembly, (Des Moines, State Printer. 1893), p. 1.

${ }^{29}$ Ibid., p. 19-21.

${ }^{30}$ Ibid., p. 19-21. 


\section{BIBLIOGRAPHY}

Superintendent of the Iowa Hospital for the Insane at Mount Pleasant. First Biennial Report to the General Assembly. Des Moines: State Printer. 1861.

Superintendent of the Iowa Hospital for the Insane at Mount Pleasant. Second Biennial Report to the General Assembly. Des Moines: State Printer. 1863.

Superintendent of the Iowa Hospital for the Insane at Mount Pleasant. Third Biennial Report to the General Assembly. Des Moines: State Printer. 1865.

Superintendent of the Iowa Hospital for the Insane at Mount Pleasant. Fourth Biennial Report to the General Assembly. Des Moines: State Printer. 1867.

Superintendent of the Iowa Hospital for the Insane at Mount Pleasant. Fifth Biennial Report to the General Assembly. Des Moines: State Printer. 1869.

Superintendent of the Iowa Hospital for the Insane at Mount Pleasant. Sixth Biennial Report to the General Assembly. Des Moines: State Printer. 1871.

Superintendent of the Iowa Hospital for the Insane at Mount Pleasant.

Seventh Biennial Report to the General Assembly. Des Moines: State Printer. 1873.

Superintendent of the Iowa Hospital for the Insane at Mount Pleasant. Eighth Biennial Report to the General Assembly. Des Moines: State Printer. 1875.

Superintendent of the Iowa Hospital for the Insane at Mount Pleasant.

Ninth Biennial Report to the General Assembly. Des Moines: State Printer. 1877.

Superintendent of the Iowa Hospital for the Insane at Mount Pleasant. Tenth Biennial Report to the General Assembly. Des Moines: State Printer. 1879.

Superintendent of the Iowa Hospital for the Insane at Mount Pleasant. Eleventh Biennial Report to the General Assembly. Des Moines: State Printer. 1881.

Superintendent of the Iowa Hospital for the Insane at Mount Pleasant. Twelfth Biennial Report to the General Assembly. Des Moines: State Printer. 1883.

Superintendent of the Iowa Hospital for the Insane at Mount Pleasant. Thirteenth Biennial Report to the General Assembly. Des Moines: State Printer. 1885.

Superintendent of the Iowa Hospital for the Insane at Mount Pleasant. Fourteenth Biennial Report to the General Assembly. Des Moines: State Printer. 1887.

Superintendent of the Iowa Hospital for the Insane at Mount Pleasant. Fifteenth Biennial Report to the General Assembly. Des Moines: State Printer. 1889.

Superintendent of the Iowa Hospital for the Insane at Mount Pleasant. Sixteonth Biennial Report to the General Assembly. Des Moines: State Printer: 1891.

Superintendent of the Iowa Hospital for the Insane at Mount Pleasant. Seventeenth Biennial Report to the General Assembly. Des Moines: State Printer. 1893. 
Superintendent of the Iowa Hospital for the Insane at Mount Pleasant. Eighteenth Biennial Report to the General Assembly. Des Moines: State Printer. 1895.

Superintendent of the Iowa Hospital for the Insane at Mount Pleasant. Nineteenth Biennial Report to the General Assembly. Des Moines: State Printer. 1897.

History of Henry County, Iowa. Chicago: Western Historical Company. 1879.

Transfer of Lands Record, Henry County. 1836-1866.

\title{
TO SAN FRANCISCO AND BEYOND The 51st Iowa Volunteers in 1898
}

\author{
by \\ WILLIAM F. STOBRIDGE \\ Arlington, Virginia
}

Mr. Strobridge, a graduate of the University of San Francisco, is a Regular Army officer stationed in the Washington, D.C. area. He came across the story of the 51st and their popularity in San Francisco while doing research on Camp Merritt.

The 51st Iowa Regiment of Infantry Volunteers rode in comparative luxury on their 1898 railroad trip to San Francisco. Unlike other Volunteers who were also ordered assembled on the Pacific Coast for the Philippine Expedition, the "boys in blue" from Iowa enjoyed plush Pullman travel instead of ordinary coach cars. The 51st arrived in San Francisco at the ferry dock after daylight on June 10, 1898 and were greeted with smiles and flowers by citizens of the city by the Golden Gate. San Franciscans cheered loudly and waved American flags when the Iowa regiment marched down Market Street to Golden Gate Avenue with bunches of flowers pinned to their hats and white calla lilies poked into their rifle barrels. They wheeled on Golden Gate and went on to Camp Merritt, a sometimes damp, sometimes dusty military tent city hastily organized three weeks before the 51st arrived to join the Far East-bound force. The 5lst had a strength of 839 officers and men under Colonel John C. Loper and the 
Copyright of Annals of Iowa is the property of State of Iowa, by \& through the State Historical Society of Iowa and its content may not be copied or emailed to multiple sites or posted to a listserv without the copyright holder's express written permission. However, users may print, download, or email articles for individual use. 